\title{
The effects of calcium and sodium loading on organic matter digestibility and mineral absorption in sheep 2. Absorption of minerals
}

\section{Hanna Leontowicz, M. Gralak, Maria Leontowicz, G. Kulasek, R. Krzemiński and Violetta Leśniewska}

\author{
Department of Animal Physiology, Warsaw Agricultural University \\ Nowoursynowska 166, 02-766 Warsaw, Poland
}

(Received 8 March, 1995; accepted 6 November 1995)

\begin{abstract}
Experiments were carried out on sheep to assess the effect of rations containing excess calcium and sodium (5 and 10 times more than recommended in the ARC requirements) on the apparent digestibility and absorption of macro- $(\mathrm{K}, \mathrm{Na}, \mathrm{Mg}, \mathrm{Ca}, \mathrm{P})$ and microelements $(\mathrm{Zn}, \mathrm{Cu})$ in the forestomachs and small intestine of sheep. The introduction of calcium lactate $(20 \% \mathrm{DM})$ into an extruded concentrates led to a significant decline in $\mathrm{Mg}$ digestibility and elevated Ca digestibility in the forestomachs and a decline in $\mathrm{P}$ digestibility in the segments of digestive tract between the mouth to the ileum (forestomachs + small intestine). Excess $\mathrm{Na}$ in the diet $(12 \mathrm{~g} / \mathrm{d}$ ) significantly reduced $\mathrm{K}$ absorption in the small intestine. Loading sheep with $\mathrm{Ca}$ and $\mathrm{Na}$ did not affect the absorption of microelements in the small intestine or in the segment between the mouth and ileum.
\end{abstract}

KEY WORDS: sheep, digestibility, absorption, minerals

\section{INTRODUCTION}

Ruminants fed some types of upgraded fibrous feeds may be exposed to excessive amounts of calcium and sodium in their diets. As the concentration of these elements in the diet rises, their specific antagonisms in terms of absorption and tissue distribution of other minerals becomes increasingly evident (Chicco et al., 1973; Bartley, 1976; NRC, 1980; Shiga and Harii, 1987; Alfaro et al., 1988). Antagonism between elements can lead to a deficit of many elements, especially 
those that normally occur in feeds at near-minimum levels (Underwood, 1977; Alfaro et al., 1988; Tucker et al., 1988).

The objective of this study was to determine the effect of rations containing excessive amounts of calcium and sodium (5 and 10 times the amount recommended in the ARC requirements) on the apparent digestibility in the forestomachs and absorption of macro- $(\mathrm{K}, \mathrm{Na}, \mathrm{Mg}, \mathrm{Ca}, \mathrm{P})$ and microelements $(\mathrm{Zn}, \mathrm{Cu})$ in the small intestine of sheep.

\section{MATERIAL AND METHODS}

\section{Animals and experimental design}

A detailed description is given in the first part of this study (Leontowicz et al., 1995). Dry matter (DM), ash, chromium (Schürch et al., 1950) were assayed in freeze-dried samples of intestinal digesta, while mineral elements were determined after mineralization the samples in concentrated $\mathrm{NHO}_{3}$ in hermetic Teflon vessels in a microwave oven. $\mathrm{K}, \mathrm{Na}, \mathrm{Mg}, \mathrm{Ca}, \mathrm{Zn}$ and $\mathrm{Cu}$ were determined in the feed, water and freeze-dried samples of duodenal and ileal digesta by atomic absorption spectrometry (Perkin Elmer 1100 B), inorganic P was determined using a kit (Biochemtest, POCH, Poland).

\section{Calculations}

Apparent digestibilities of ash and the analyzed mineral components in forestomachs and small intestine were calculated on the basis of the $\mathrm{Cr}_{2} \mathrm{O}_{3}$ content in the duodenal and ileal digesta using Ruszcryc's formula (1983).

TABI.F, 1

The mineral content of rations for sheep, $\mathrm{g} / \mathrm{kg} \mathrm{DM}$

\begin{tabular}{lcccc}
\hline & \multicolumn{3}{c}{ Extruded concentrate } & \\
\cline { 2 - 4 } Minerals & $\begin{array}{c}\text { I } \\
\text { control }\end{array}$ & $\begin{array}{c}\text { II } \\
\text { Ca-loading }\end{array}$ & $\begin{array}{c}\text { III } \\
\text { Na-loading }\end{array}$ & Meadow hay \\
\hline Ash & 53.68 & 149.41 & 169.70 & 82.22 \\
$\mathrm{Mg}$ & 2.81 & 2.77 & 2.90 & 2.16 \\
$\mathrm{Ca}$ & 7.99 & 45.28 & 14.46 & 6.67 \\
$\mathrm{P}$ & 3.33 & 4.88 & 5.28 & 3.58 \\
$\mathrm{Na}$ & 1.13 & 3.28 & 30.00 & 1.22 \\
$\mathrm{~K}$ & 9.40 & 8.03 & 8.58 & 15.75 \\
$\mathrm{Cu}$ & 0.02 & 0.03 & 0.03 & 0.02 \\
$\mathrm{Zn}$ & 0.05 & 0.10 & 0.10 & 0.04 \\
\hline
\end{tabular}


The results were subjected to statistical analysis of variance using Statgrafics software, while the significance of differences between means was assessed by the Tukey test.

\section{RESULTS}

The intake of extruded concentrates, hay and water is described in a previous paper (Leontowicz et al., 1995). Table 2 gives the apparent digestibility coefficients of ash, $\mathrm{Mg}, \mathrm{Ca}$ and $\mathrm{P}$ in the forestomachs and small intestine. Intake of minerals was from 43 (I) to $91 \mathrm{~g}$ (II) designated as ash in the diets $(\mathrm{P}<0.05)$. The digestibility coefficients of ash in the forestomachs were negative in groups I and II ( -89 and $-30 \%$, respectively) and positive in group III $(+6 \% ; \mathrm{P}<0.05)$, while in the small intestine they were higher in the control group $(85 \%)$ than in the calcium and sodium groups ( 41 and $37 \%$, respectively; $P<0.05$ ). In sheep loaded with $\mathrm{Na}$, ash digestibility in the segment between the mouth and ileum (forestomach + small intestine) was higher than in the remaining groups $(\mathrm{P}<0.05)$.

At a similar $\mathrm{Mg}$ intake, its digestibility in the forestomachs was lower in the calcium group $(27 \%)$ than in groups I and III $(55$ and $44 \% ; \mathrm{P}<0.05)$; the respective values in the small intestine ranged from -10 (III) to $+5 \%$ (I). Calcium intake differed among groups $(\mathrm{P}<0.05 ;$ Table 2$)$. In sheep loaded with $\mathrm{Ca}$ and $\mathrm{Na}$, calcium digestibility in the forestomachs was higher than in the control group $(\mathrm{P}<0.05)$, and ranged from +8 (I) to $-8 \%$ (III) in the small intestine. Negative $P$ digestibility in the forestomach was found in all of the groups, while in the small intestine its digestibility coefficients ranged from 80 (II) to $98 \%$ (I); in the segment between the mouth and ileum, $P$ digestibility was lower in the sodium group in comparison with the control $(\mathrm{P}<0.05)$.

The apparent digestibility coefficients of $\mathrm{Na}, \mathrm{K}, \mathrm{Cu}$ and $\mathrm{Zn}$ in the digestive tract of sheep are presented in Table 3. Sodium intake equalled from 0.8 (I) to 12 $\mathrm{g} / \mathrm{d}$ (III). Digestibility coefficients of $\mathrm{Na}$ in the forestomachs were negative and differed significantly among groups $(\mathrm{P}<0.05)$. Na digestibility in the small intestine and in the segment between the mouth and ileum was highly varied $(\mathrm{P}<0.05)$.

Potassium intake was similar in all groups. Its digestibility in the forestomachs in the Na-loaded group was higher, while in the small intestine lower $(\mathbf{P}<0.05)$ than in sheep fed the control and calcium diets. The $\mathrm{K}$ digestibility in the segment from the mouth to ileum in sheep loaded with $\mathrm{Na}$ and $\mathrm{Ca}$ were higher $(\mathrm{P}<0.05)$ than in the animals on the control diet (78 and 82 vs $66 \%$ ).

No significant differences were found between groups in the apparent digestibility of $\mathrm{Cu}$ in the forestomachs $(58-65 \%)$, small intestine $(0.2-1.0 \%)$ or in the segment between the mouth and ileum (59-66\%). 
TABLE 2

Ash digestibility and $\mathrm{Mg}, \mathrm{Ca}$ and $\mathrm{P}$ digestibilities in the forestomachs and small intestine of sheep $(\mathrm{x} \pm \mathrm{SD} ; \mathrm{n}=12=3$ sheep $\mathrm{x} 2$ samples $\mathrm{x} 2$ collections)

\begin{tabular}{|c|c|c|c|}
\hline \multirow[b]{2}{*}{ Indices } & \multicolumn{3}{|c|}{ Group } \\
\hline & $\begin{array}{c}\text { I } \\
\text { control }\end{array}$ & $\begin{array}{c}\text { II } \\
\text { Ca-loading }\end{array}$ & $\begin{array}{c}\text { III } \\
\text { Na-loading }\end{array}$ \\
\hline \multirow[t]{2}{*}{ Ash intake, $\mathrm{g} / \mathrm{d}$} & $43 \pm 5^{a}$ & $85 \pm 2^{b}$ & $91 \pm 6^{c}$ \\
\hline & \multicolumn{3}{|c|}{ Apparent digestibility coefficients of ash, $\%$ : } \\
\hline forestomachs' & $-89 \pm 31^{x}$ & $30 \pm 28^{b}$ & $61 \pm 4^{c}$ \\
\hline small intestine ${ }^{2}$ & $85 \pm 25^{a}$ & $41 \pm 29^{b}$ & $37 \pm 31^{b}$ \\
\hline forestomachs + small intestine $^{3}$ & $-3 \pm 29^{a}$ & $11 \pm 15^{\mathrm{a}}$ & $43 \pm 10^{6}$ \\
\hline \multirow[t]{2}{*}{ Mg intake, $\mathrm{g} / \mathrm{d}$} & $1.7 \pm 0.1$ & $1.8 \pm 0.1$ & $1.8 \pm 0.2$ \\
\hline & \multicolumn{3}{|c|}{ Digestibility coefficients of $\mathrm{Mg}, \%$} \\
\hline forestomachs & $55.4 \pm 21.7^{\mathrm{a}}$ & $27.2 \pm 15.4^{\mathrm{b}}$ & $44.1 \pm 9.8^{\mathrm{a}}$ \\
\hline small intestine & $4.5 \pm 22.1$ & $1.4 \pm 26.9$ & $-9.8 \pm 24.8$ \\
\hline forestomachs + small intestine & $57.9 \pm 11.9$ & $28.6 \pm 20.0$ & $34.3 \pm 15.7$ \\
\hline \multirow[t]{2}{*}{$\mathrm{Ca}$ intake, $\mathrm{g} / \mathrm{d}$} & $5.1 \pm 0.5^{\mathrm{a}}$ & $19.7 \pm 0.2^{b}$ & $8.0 \pm 0.5^{\mathrm{c}}$ \\
\hline & \multicolumn{3}{|c|}{ Digestibility coefficients of $\mathrm{Ca}, \%$} \\
\hline forestomachs & $1.1 \pm 16.4^{\mathrm{a}}$ & $26.5 \pm 13.8^{b}$ & $24.3 \pm 14.1^{\mathrm{b}}$ \\
\hline small intestinc & $7.9 \pm 25.7$ & $0.5 \pm 25.4$ & $-8.4 \pm 32.2$ \\
\hline forestomachs + small intestine & $9.0 \pm 24.4$ & $27.0 \pm 20.2$ & $15.9 \pm 19.8$ \\
\hline \multirow[t]{2}{*}{$P$ intake, $g / d$} & $2.3 \pm 0.2^{4}$ & $2.6 \pm 0.1^{b}$ & $2.5 \pm 0.3^{\mathrm{ab}}$ \\
\hline & \multicolumn{3}{|c|}{ Digestibility coefficients of $\mathrm{P}, \%$} \\
\hline forestomachs & $-45.7 \pm 27.2$ & $-55.5 \pm 27.5$ & $-57.7 \pm 25.8$ \\
\hline small intestine & $97.6 \pm 28.8$ & $80.1 \pm 34.1$ & $88.0 \pm 18.4$ \\
\hline forestomachs + small intestine & $51.9 \pm 11.7^{\mathrm{a}}$ & $24.8 \pm 17.4^{b}$ & $30.9 \pm 19.8^{\mathrm{ab}}$ \\
\hline
\end{tabular}

a, b, c $-\mathrm{P}<0.05$

' forcstomachs $=$ intake minus duodenum

${ }^{2}$ small intestine $=$ duodenum minus ileum

${ }^{3}$ forestomachs + small intestine $=$ intake minus ileum

Despite high variability related to secretion of $\mathrm{Zn}$ into the small intestine, its apparent digestibility in the forestomachs was lower in the control sheep (-69\%) than in the animals from the sodium group $(-34 \%)$. Large individual variations were observed in the small intestine, but an average $\mathrm{Zn}$ digestibility ranging from $14 \%$ in the Na-loaded group to $26 \%$ in the control group were found. 


\section{DISCUSSION}

In the present study, it was found that the $\mathrm{Mg}, \mathrm{Ca}$ and $\mathrm{Cu}$ content in the digesta entering to the duodenum was lower than the amount intake with the ration (Tables 2 and 3). The positive apparent digestibility coefficients obtained for these elements in the forestomachs point to their absorption in this part of the digestive tract. The flow of the remaining elements, i.e. Na, $\mathrm{P}, \mathrm{Zn}$, and partially $\mathbf{K}$, through the duodenum was greater than intake. This indicates high concentration of these elements in saliva and digestive juice (McDowell, 1992). At the negative apparent digestibility of these elements in the forestomachs, their main site of absorption was the small intestine (Tables 2 and 3).

TABLE 3

$\mathrm{K}, \mathrm{Na}, \mathrm{Cu}$ and $\mathrm{Zn}$ digestibilitics in forestomachs and small intestine of sheep $(\mathrm{x} \pm \mathrm{SD}$; $\mathrm{n}=12=3$ sheep $\times 2$ samples $\times 2$ collections)

\begin{tabular}{|c|c|c|c|}
\hline \multirow[b]{2}{*}{ Indices } & \multicolumn{3}{|c|}{ Group } \\
\hline & $\begin{array}{c}\mathrm{I} \\
\text { control }\end{array}$ & $\begin{array}{c}\text { II } \\
\text { Ca-loading }\end{array}$ & $\begin{array}{c}\text { III } \\
\text { Na-loading }\end{array}$ \\
\hline $\mathrm{Na}$ intake, $\mathrm{g} / \mathrm{d}$ & $0.8 \pm 0.1^{\mathrm{a}}$ & $1.7 \pm 0.1^{\mathrm{b}}$ & $11.9 \pm 0.1^{c}$ \\
\hline $\begin{array}{l}\text { forestomachs } \\
\text { small intestine }{ }^{2} \\
\text { forestomachs }+ \text { small intestine }\end{array}$ & $\begin{array}{r}\text { Dig } \\
-1630 \pm 491^{\mathrm{a}} \\
908 \pm 365^{\mathrm{a}} \\
-722 \pm 324^{\mathrm{a}}\end{array}$ & $\begin{array}{l}\text { lity coefficients } \\
\begin{array}{l}-700 \pm 221^{\mathrm{b}} \\
333 \pm 259^{\mathrm{b}} \\
-368 \pm 120^{\mathrm{b}}\end{array}\end{array}$ & 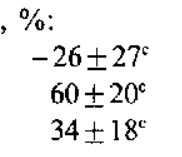 \\
\hline $\mathrm{K}$ intake, $\mathrm{g} / \mathrm{d}$ & $7.8 \pm 1.0$ & $8.5 \pm 0.4$ & $8.4 \pm 1.1$ \\
\hline $\begin{array}{l}\text { forestomachs } \\
\text { small intestine } \\
\text { forestomachs }+ \text { small intestine }\end{array}$ & $\begin{array}{r}\text { Dig } \\
-18.2 \pm 32.7^{\mathrm{a}} \\
84.5 \pm 30.0^{\mathrm{a}} \\
66.3 \pm 15.9^{\mathrm{a}}\end{array}$ & $\begin{array}{l}\text { lity coefficients } \\
10.8 \pm 30.8^{\mathrm{a}} \\
88.6 \pm 34.2^{\mathrm{a}} \\
77.8 \pm 6.8^{\mathrm{b}}\end{array}$ & $\begin{array}{l}\% \\
30.2 \pm 18.2^{\mathrm{b}} \\
52.1 \pm 18.5^{\mathrm{b}} \\
82.3 \pm 3.2^{\mathrm{b}}\end{array}$ \\
\hline $\mathrm{Cu}$ intake, $\mathrm{g} / \mathrm{d}$ & $12.6 \pm 1.5^{\mathrm{a}}$ & $20.6 \pm 0.6^{\mathrm{b}}$ & $17.1 \pm 1.6^{\mathrm{c}}$ \\
\hline $\begin{array}{l}\text { forestomachs } \\
\text { small intestine } \\
\text { forestomachs }+ \text { small intestine }\end{array}$ & $\begin{array}{r}\text { Dig } \\
57.6 \pm 10.6 \\
1.0 \pm 8.7 \\
58.6 \pm 13.9\end{array}$ & $\begin{array}{l}\text { ity coefficients } \\
64.8 \pm 6.0 \\
0.9 \pm 5.9 \\
65.6 \pm 5.4\end{array}$ & $\begin{array}{r}\% \\
63.4 \pm 2.7 \\
0.2 \pm 4.4 \\
63.6 \pm 4.6\end{array}$ \\
\hline $\mathrm{Zn}$ intake and flow, $\mathrm{g} / \mathrm{d}$ & $33.0 \pm 3.4^{\mathrm{a}}$ & $54.1 \pm 1.4^{b}$ & $55.0 \pm 3.0^{\mathrm{b}}$ \\
\hline $\begin{array}{l}\text { forestomachs } \\
\text { small intestine } \\
\text { forestomachs }+ \text { small intestine }\end{array}$ & $\begin{array}{r}\mathrm{Dig} \\
-68.8 \pm 35.9^{\mathrm{a}} \\
26.4 \pm 30.3 \\
-42.4 \pm 47.2^{\mathrm{a}}\end{array}$ & $\begin{array}{l}\text { lity coefficients } \\
-52.3 \pm 26.5^{\mathrm{ab}} \\
22.3 \pm 31.1 \\
-30.1 \pm 22.2^{\mathrm{b}}\end{array}$ & $\begin{array}{l}\% \\
-34.4 \pm 17.2^{b} \\
14.4 \pm 13.4 \\
-20.1 \pm 16.4\end{array}$ \\
\hline
\end{tabular}

a, b, c - P $<0.05$

$1,2,3$ legend as in Table 2 
Loading an extruded concentrates with $\mathrm{Ca}$ ( 5 times the ARC requirement) lowered $\mathrm{Mg}$ digestibility $(27 \%)$ in the forestomachs in comparison with the control $(55 \%)$ and sodium $(44 \%)$ groups $(\mathrm{P}<0.05)$. Chicco et al. (1973), Ben Ghedalia et al. (1982) and McDowell (1992) also observed lower Mg absorption in sheep loaded with $\mathrm{Ca}$, indicating on important role of the forestomachs in $\mathrm{Mg}$ absorption and the marginal role of the small intestine. The increase in Ca intake with the ration from 5 (group l) to $19 \mathrm{~g} / \mathrm{d}$ (group II) increased the Ca flow throughout the duodenum and ileum and the digestibility of $\mathrm{Ca}$ in the forestomachs $(\mathrm{P}<0.05)$, while at the same time reducing its digestibility in the small intestine. Ca digestibility in the small intestine (Table 2) concerns the amount of $\mathrm{Ca}$ absorbed in the intestine between duodenal and ileal cannulas. Other authors reported that the main site of $\mathrm{Ca}$ absorption (both active and passive) is the duodenum and noted a lowering of $\mathrm{Ca}$ concentration in the entire digestive tract when loading sheep with $\mathrm{Ca}$ (Ben Ghedalia et al., 1982). Ca absorption is facilitated by a low pH. According to Braithwait (1974) it is dependent on the requirement status of the animal which declines with age. In our experiments, a reduction of $\mathrm{Ca}$ absorption in the small intestine occurred when the Ca:P ratio rose from 2:1 in the control group to 7:1 in the Ca group, while the recommended level is from 1:1-2:1 (McDowell, 1992).

The negative digestibility of $\mathrm{P}$ in the forestomachs of all of the sheep (46-56\%) was the result of the high concentration of this element in the saliva, stomach and pancreatic juices (a cannula located behind the junction with the pancreatic-bile ducl). In the Ca-loaded group, a fall in P digestibility was found in the segment between the mouth and ileum, most likely due to its decline in the small intestine. The absorption of $\mathbf{P}$ in the small intestine ranged within 98 (I) to $80 \%$ (II). According to INRA (1989), absorption of P declines with age from 80 to $50 \%$, so in our sheep (5-6 months old) this parameter was in the upper range of these standards. High $\mathrm{P}$ absorption coefficients in the small intestine of growing sheep in our studies declined when the Ca:P ratio in the diet increased. McDowell (1992) reported the close relationship between net $\mathrm{P}$ absorption in the small intestine and secretion of $P$ in the saliva, which can play an important role in homeostasis by controlling the secretion of $\mathrm{P}$ to the large intestine.

The absorption of $\mathrm{Na}$ from rations differed among groups and equalled from 0.8 to $12 \mathrm{~g} / \mathrm{d}$, while its flow through the duodenum equalled about $14 \mathrm{~g} / \mathrm{d}$ in all of the groups (Table 3). These results indicate that there was a large amount of $\mathrm{Na}$ supplied with saliva and intestinal juices to the duodenum of sheep in groups I and II, which according to NRC (1980) is about $80 \%$. Sodium ions play an important role in absorption of sugars and amino acids in the small intestine (Grim, 1980), but an excess of $\mathrm{Na}$ in the ration did not affect total nitrogen absorption in the small intestine in the same animals (Leontowicz et al., 1995). In these studies, significant differences were found between groups in $\mathrm{Na}$ 
digestibility in the studied segments of the digestive tract; the highest absorption of $\mathrm{Na}$ in the small intestine was in control sheep (98\%), the lowest in the sheep loaded with $\mathrm{Na}(60 \% ; \mathrm{P}<0.05)$. According to ARC $(1980)$, absorption of $\mathrm{Na}$ in the small intestine is complete, INRA standards give a value of $90 \%$.

The relationship between loading sheep with $\mathrm{Na}$ (or $\mathrm{Ca}$ ) and the dynamics of digestive processes and between $\mathrm{pH}$ values and the dynamics of some elements in the rumen were discussed in earlier studies (Leontowicz et al,, 1995). When animals are loaded with $\mathrm{Na}$, the sodium level of the saliva rises while that of potassium decreases; a similar relationship between the $\mathrm{Na}$ and $\mathrm{K}$ concentrations in the rumen was found by Chii and Phillips (1993). In our studies on sheep loaded with $\mathrm{Na}$ we found a significant decline in $\mathrm{K}$ digestibility in the small intestine from 84.5 in group I to $52.1 \%$ in group III and its rise in the segment between the forestomachs and ileum (Table 3 ). The differences in the digestibility coefficients result from the antagonism between $\mathrm{Na}$ and $\mathrm{K}$. According to the INRA (1989) the $\mathrm{K}$ absorption coefficients in the small intestine equal $80 \%$; we obtained similar values for our control sheep.

The $\mathrm{Cu}$ content in the control ration, despite its high concentration in the feeds, was in the medium range of NCR standards (1980), while in the calcium group, in the upper range. Cu digestibility in the studied segments of the digestive tract was positive; equalling from 58 to $63 \%$ in the forestomachs, which indicates that $\mathrm{Cu}$ already began to be absorbed in the forestomachs or intensely in the duodenum, before reaching the cannula situated just behind the pancreatic-bile duct orifice. Similarly as in the case of $\mathrm{Mg}$, absorption of $\mathrm{Cu}$ in the small intestine was not large (Table 3). Loading with $\mathrm{Ca}$ did not significantly affect its distribution in the digestive tract or absorption, which has been reported in the works of Alfaro et al. (1988) and Tucker et al. (1988). McDowell (1992) reports that absorption of $\mathrm{Cu}$ in adult ruminants ranges from 1 to $3 \%$, emphasizes its variability and the occurrence of numerous interactions with other dietary components such as phytins, $\mathrm{Ca}, \mathrm{Zn}, \mathrm{Fe}$. Underwood (1977) found reduced $\mathrm{Cu}$ absorption in the presence of high $\mathrm{Ca}$ and $\mathrm{Zn}$ concentrations in the diet.

No differences were found in $\mathrm{Zn}$ digestibility in sheep loaded with $\mathrm{Ca}$ or $\mathrm{Na}$. $\mathrm{Zn}$ digestibility in the small intestine ranged from 26 in group I to $14 \%$ in group III (Table 3). Absorption of $\mathrm{Zn}$ depends on its intake in the diet. When its level in the ration is lowered, its absorption is higher than when rations with a higher $\mathrm{Zn}$ content are fed. In the latter case, absorption can fall to $10 \%$ (McDowell, 1992). Similar tendencies were observed in our studies when $\mathrm{Zn}$ digestibility in the small intestine declined when its dietary intake rose. 


\section{CONCLUSIONS}

The introduction of excessive amounts of calcium lactate (20\% DM) into the composition of an extruded concentrates for sheep significantly lowered apparent $\mathrm{Mg}$ digestibility coefficients and increased them for $\mathrm{Ca}$ in the forestomachs and lowered $\mathbf{P}$ digestibility in the segment between the mouth and ileum.

The main sites of net $\mathrm{Mg}$ and $\mathrm{Cu}$ absorption were the forestomachs and/or the first part of the duodenum, while $\mathrm{Na}, \mathrm{K}$ and $\mathrm{P}$ were absorbed mainly in the small intestine, regardless of $\mathrm{Ca}$ or $\mathrm{Na}$ loading.

Excess $\mathrm{Na}$ in the diet for sheep $(12 \mathrm{~g} / \mathrm{d}$ ) significantly lowered $\mathrm{K}$ absorption in the small intestine.

Loading sheep with $\mathrm{Ca}$ and $\mathrm{Na}$ did not affect absorption of the studied microelements in the small intestine or in the segment between the mouth and ileum.

\section{REFERENCES}

Alfaro E., Neathery M.W., Miller W.J., Crowe C.T., Gentry R.P., Fielding A.S., Pugh D.G., Blackman D.M., 1988. Influence of wide range of calcium intake on tissuc distribution of macroelements and microclements in dairy calves. J. Dairy Sci. 71, 1295-1300

ARC, 1980. The Nutrient Requirement of Ruminant Livestock. Commonwealth Agric. Bureaux, London

Bartley E.E., 1976. Bovine saliva production and function. In: M.S.Weinburg, A.L. Sheffner (Editors), Buffers in ruminant physiology and metabolism. New York. NY: Church and Dwight, Inc. pp. 23-38

Ben Ghedalia D., Tagari H., Gevva A., 1982. Absorption by sheep of calcium, phosphorus and magnesium from a poultry litter supplemented diet. J. Agric. Sci., Camb. 98, 85-88

Braithwaitc G.D., 1974. The effect of changes of dietary calcium concentration on calcium metabolism in sheep. Brit. J. Nutr. 31, 319-331

Chicco C.F., Ammerman C.B., Loggins P.E., 1973. Effect of age and dietary magnesium on voluntary feed intakc and plasma magnesium in ruminants. J. Dairy Sci. 56, 822-824

Chiy P.C., Phillips C.J.C., 1993. Sodium fertilizer application to pasture. 1. Direct and residual effects on pasture production and composition. Grass Forage Sci. 48, 189-202

Grim E., 1980. In: Sodium in Medicine and Health. C. Moses (Editor), Reese Press, Baltimore, Maryland, p.11

INRA, 1989. Ruminants Fecding (in Polish). R. Jarrige (Editor), The Kielanowski Institute of Animal Physiology and Nutrition, Polish Academy of Sciences, Jablonna, 1993

Leontowicz II., Krzemiński R., Leontowicz M., Kulasek G., Gralak M., Leśnicwska V., 1995. The effect of calcium and sodium loading on organic matter digestibility and mineral absorption in sheep. 1. Digestion in the forestomachs and small intestine. J. Anim. Feed Sci. 4, 299-309

McDowell L.R., 1992. Minerals in Animal and Human Nutrition. Academic Press Inc., San Diego, New York 
NRC, 1980. Mineral Tolerance of Domestic Animals. National Acadcmy of Sciences, National Research Council, Washington, D.C.

Ruszczyc Z., 1983. Animals Feeding and Feed Science (in Polish). PWRiL, Warsaw

Schürch A.F., Lloyd L.E., Crampton E.W., 1950. The use of chromic oxide as an index for determining the digestibility of a diet. J. Nutr. 41, 629-636

Shiga A., Horii N., 1987. Effects of pH, Ca and P on the formation of Mg precipitate. J. Fac. Agric. Iwate Univ. 18, 303-311

Tucker W.B., Xin Z., Hemken R.W., 1988. Influence of dietary calcium chloride on adaptative changes in acid base status and mineral metabolism in lactating dairy cows fed a diet high in sodium bicarbonate. J. Dairy Sci. 71, 1587-1597

Underwood E.J., 1977. Trace Elements in Human Nutrition. Academic Press Inc., New York, London

\section{STRESZCZENIE}

Wpływ nadmiaru wapnia lub sodu $w$ diecie na trawienie składników organicznych $\mathbf{i}$ wchłanianie związków mineralnych u owiec. 2 . Wchłanianie składników mineralnych

W doświadczeniu przeprowadzonym na owcach badano wpływ dawek pokarmowych zawierających nadmiar $\mathrm{Ca}$ i Na (5 i 10-krotnie więcej niż zapotrzebowanie wg ARC) na strawność pozorną oraz wchłanianic makro (K, Na, Mg, Ca, P) i mikrociementów ( $\mathrm{Zn}, \mathrm{Cu}$ ) w przcdizołądkach i jelicic cienkim. Wprowadzenie mleczanu wapniowego (20\% s.m.) w sklad ekstrudowanej mieszanki treściwej wpłynęło na istotne obniżenie strawności $\mathrm{Mg}$ i podwyższenie strawności Ca w przedżołądkach i spadek strawności P na odcinku do jelita bjodrowego. Nadmiar $\mathrm{Na} w$ dawce $(12 \mathrm{~g} / \mathrm{d})$ istotnie obniżał wchłanianic $\mathrm{K}$ w jelicic cienkim i zwiększał wchłanianie Zn z przcdżołądków. Obciążanie owiec $\mathrm{Ca}$ i $\mathrm{Na}$ nie wpływało na wchłanianie mikroelementów w jelicie cienkim i na odcinku do jelita biodrowego. 